\title{
'Providential' Campaigns: Intertwining Thuggee and the Sepoy Mutiny in Colonial Fictions
}

\author{
Ayusman Chakraborty \\ Assistant Professor of English (W.B.E.S), Taki Government College, New Town. Rajarhat, \\ Kolkata. ORCID: oooo-0003-0641-0652. Email: hinduayusman@gmail.com
}

\begin{abstract}
:
This article examines how some colonial fictions intertwine historically unconnected Thuggee and the Sepoy Mutiny of 1857 to make sense of Indian resistance to British rule. This was done by only a few writers. The article tries to find out what led these colonial writers to link the two unconnected events. To do this, representations of Thuggee and the Mutiny in the works of Captain Meadows Taylor, Sir Arthur Conan Doyle, and Emilio Salgari are scrutinized. The article also considers other relevant works, like those by Sir George MacMunn, Hermann Goedsche, Jules Verne and Francisco Luis Gomes. It tries to ascertain whether a writer's nationality affected his conceptualization of the relationship between Thuggee and the Mutiny in any significant way. In doing so, it seeks to highlight how representations of Indian insurgency in colonial writings varied in accordance with the writer's nationality and outlook vis-à-vis British colonialism in India.
\end{abstract}

Keywords: Thuggee, Sepoy Mutiny, Insurgency, Colonial Fiction, Meadows Taylor, Doyle, Salgari.

\section{Introduction}

While British India was still being ravaged in 1858 in the aftermath of the Uprising of $1857^{1}$, in England the publisher Richard Bentley decided to bring out a new cheaper one volume edition of Captain Philip Meadows Taylor's Confessions of a Thug. At first glance, he appears to have made a daring choice. Originally published by the same publisher in 1839 , the novel had been a one-time bestseller. But by 1858 , its popularity had considerably waned. This is proven by the simple fact that though the second edition quickly came out in 1840, no subsequent edition followed till 1858 (for publication data see Finkelstein 1990, 21). Therefore, the publisher could not have been oblivious of taking a considerable risk in republishing the former bestseller after a gap of eighteen years. He might have banked on the possibility of this cheaper one volume edition finding more buyers than the earlier costly three volume ones. But for a veteran businessman like Bentley, this would surely have seemed an insufficient allurement for investing in an uncertain venture. More likely, he discerned something advantageous in the situation current at that time. As the new "Preface" added to the 1858 edition by the writer's father Senior Philip Meadows Taylor makes clear $^{2}$, it was hoped that the novel would be able to capitalize upon the recent upsurge of British interest in India. In the words of Senior Taylor, the publication of a revised edition would have been unnecessary "but for the present absorbing interest of Indian affairs" (P.M.T. n.d., n.p.). As might be imagined, that "absorbing interest" was an outgrowth of the Indian Uprising or the Sepoy Mutiny of $1857 .{ }^{3}$ The "Preface" went on to provide further justifications for the publication

(c) AesthetixMS 2020. This Open Access article is published under a Creative Commons Attribution Non-Commercial 4.o International License (http://creativecommons.org/licenses/by-nc/4.o/), which permits non-commercial re-use, distribution, and reproduction in any medium, provided the original work is properly cited. For citation use the DOI. For commercial re-use, please contact editor@rupkatha.com. 
of the new edition, drawing a curious parallel between Thuggee and the Sepoy Mutiny in the process.

In the "Preface", Senior Taylor interprets both Thuggee and the Sepoy Mutiny as conspiracies hatched by the Indians. He finds that in both cases the Indians managed to deceive the British for at least a considerable length of time. He explains,

It [the novel] may also furnish some clue to the successful concealment of a rebellion, in the existence of which many of our oldest and most experienced officers, and men high in authority, absolutely withheld belief, till too late and too cruelly convinced of their fatal error (P.M.T. n.d., n.p.).

There is no doubt that his son Captain Taylor influenced his father's view in this matter. Captain Meadows Taylor, who served as an administrator in India from 1824 to 1860, was a self-declared specialist on India (see his autobiography, Taylor 1878, sic passim). He linked Thuggee with the Mutiny in one of his letters to his family. To both father and son, Thuggee and the Sepoy Mutiny epitomized the deceptiveness of the Indians and the gullibility of the Britons. Implicit in this assumption was an advice to the Britons to remain ever vigilant against the Indians. Kim A Wagner's observation becomes particularly relevant in this regard. He maintains, "The Thugs and the Uprising of 1857 embodied all that the British feared from their Indian subjects; when combined they constituted the ultimate scenario of colonial paranoia" (Wagner 2010, 9; also, Wagner 2013, 158).

It would however be a mistake to think that the publisher and the author party tried to popularize the novel once again simply by tapping into the already increasing British paranoia. More likely, the publisher felt that the novel's reformist message would attract the (British) reading public specifically during that period. As originally published, Confessions of a Thug sought to vindicate British civilizing mission in India. The original 1839 "Introduction" ended with the plea that:

If this volume in any way contribute to awaken public vigilance in the suppression of Thuggee, or if from the perusal of it, any one in authority rises with a determination to lend his exertions in this good cause of humanity, my time will not have been occupied in vain (Taylor n.d., viii).

As Kim A. Wagner has pointed out, in 1839 such an appeal was purposeless because "[T]huggee had all but ceased to exist" by that period. He feels that this appeal only imbues the novel with "false reformist significance" (Wagner 2009, 38). One presumes that this was just a strategy of attracting self-righteous readers of that period. However, this reformist message was sure to find more takers in 1858 than in 1839. To many at this period, including Captain Meadows Taylor himself, the Sepoy Mutiny revealed that the task of 'civilizing' the Indians was far from over. In this regard, it was similar to Thuggee. Both were cited as proofs of 'native savagery'. At the same time, both could justify the continuation of the 'civilizing mission'. That in turn could be used as an argument for vindicating the indefinite prolongation of colonial rule in India.

This article examines how some nineteenth and early twentieth century colonial authors intertwined Thuggee with the Sepoy Mutiny in order to present Indian resistance to British rule in a specific light. In doing so, they often evaluated the extent of British success in 'civilizing', Christianizing, or Anglicizing the Indians. It must be admitted beforehand that this article does not intend to provide new insights into either Thuggee or the Sepoy Mutiny. It is solely concerned with textual representations of these. Instead of calling into question the veracity of colonial representations of either, this article seeks to explain how and why some writers interconnected 
Thuggee and the Mutiny. In the process, the article reveals how an individual writer's nationality, as well as his attitude towards British colonialism, influenced the manner in which he interconnected Thuggee and the Mutiny. To achieve this end, this article scrutinizes and compares three European works which associate these two events. These are Captain Taylor's Seeta (1872), Conan Doyle's “Uncle Jeremy's Household” (1887), and Emilio Salgari's Sandokan: The Two Tigers (1904). While the focus is mainly on these works, other relevant texts are also inspected as per requirement. The article focuses primarily on fiction because colonial histories seldom suggested a connection between Thuggee and the Mutiny. This fact requires some explanation, which will be attempted as we proceed. It is sufficient to mention at this point that works of fiction are less fettered by facts than historical writings. So authors can take more liberties in these. But this does not mean that these particular works are irrelevant. They are of interest to us in as much as they reflect the assumptions of a section of people of that period. It is also to be noted that fictional works linking Thuggee and the Sepoy Mutiny are very few in number. This is probably because official history never sanctioned this idea.

Without some background knowledge, one would find it difficult to understand why some European writers associated Thuggee with the Sepoy Mutiny. The next section shows how the two became associated in colonial imagination.

\section{Through the Colonizers' Eyes: The 'Providential' Natures of British Anti-Thuggee Campaign and the Sepoy Mutiny}

It is now well recognized that the discovery of Thuggee in the early nineteenth century was one of the watershed moments in the history of British India. As understood by British and European writers, Thuggee was a synthesis of highway banditry and murderous cult whose practitioners worshipped Goddess Kali and preyed upon travellers on the road. ${ }^{4}$ Sir William Henry Sleeman was the first to describe British campaign against Thuggee as "providential". ${ }^{5}$ In his magnum opus Ramaseeana (1836) he observed that the campaign was favoured by "a combination of circumstances so fortunate" that it almost appeared "providential" (Sleeman 1836, 47). But the word 'providential' also reminds us of Radhika Singha's pioneering article "Providential' Circumstances: The Thuggee Campaign of the 1830 os and Legal Innovation" (Singha 1993, .83 146). As suggested by her, and later elaborated upon by others, the campaign against Thuggee was strategically used by the colonial government to justify paramountcy and intervention in internal management of the princely states (Singha 1993, 88; but especially Roy, 1996: 130, 132; Chatterjee, 1998: 5, 125 - 141). The British anti-Thuggee campaign was thus 'providential' in an ironic sense. As Caroline Reitz declares, "if Thuggee had not been 'discovered', it would have had to be invented" (Reitz 2004, 98; also see, Chatterjee 1998; 5). However, this article shows that the discovery of Thuggee was also 'providential' to the colonizing British in a different way. Thuggee provided the colonizers with an instance that could be summoned again and again to undermine Indian resistance against British rule.

Thuggee continues to remain a controversial topic in our age with scholars debating whether it was simply a colonial construction or a social reality (for an overview see Chakraborty 2019, 344 - 347). However, such issues are inconsequential for this present study which is concerned not with what it actually was but with what use the British made of it. It becomes apparent that as time progressed the colonial authorities increasingly came to look upon Thuggee as a pan-Indian conspiracy against life, law and order in which both the Hindus and the Muslims were involved. Kim A. Wagner aptly observes, "The Thugs are to colonial conspiracy theories of the Raj what the Templars are to their European counterparts" (Wagner 2013, 156). Following C. A. 
Bayly, he situates British fear of the Thugs in the broader context of "information panic". To the British, the Thugs represented that aspect of India which ever escaped the gaze of the colonizers. Naturally, the British colonizers were quick to draw parallels between Thuggee and other 'conspiracies' against their rule. An observation of Cynthia Ann Humes appears significant in this context. She points to the fact that while the British initially looked upon Thuggee and its patron Goddess Kali as menaces that threatened only the Indian populace, ${ }^{6}$ in the later years, especially after the Mutiny, they viewed both as being direct threats to themselves (Humes 2003, 159 - 161; also, Urban 2003, 85). No doubt this perception was reinforced to a large extent by the activities of the Indian (Hindu) nationalists who appropriated Goddess Kali as their icon.

In his book Tantra: Sex, Secrecy, Politics and Power in the Study of Religion Hugh B. Urban describes how the British colonizers and the Hindu nationalists drew Goddess Kali into an ideological battle between themselves. Following an idea first suggested by the Bengali author Bankim Chandra Chattopadhyay in his 1882 novel Anandamath (English, The Abbey of Bliss), the (Hindu) freedom fighters imaginatively identified the motherland with Goddess Kali. Particularly, armed insurrection against the British colonizers became a sort of sacred duty to the radical (Hindu) revolutionaries in Bengal. As the radical Bengali newspaper Jugantar hyperbolically called it in 1905, this was sacrificing "many white Asuras" to Goddess Kali, or "slaying the Feringhee white goat[s]" (cited in Urban 2003, 73). Urban explains that this was not merely legitimizing revolutionary terrorism through an appeal to religion. For the insurrectionists, this also meant appropriating the colonizers' representations of Goddess Kali and inverting these to "counterhegemonic weapons of resistance" (Urban 2003, 88 - 93). On the British side, the colonizers quickly related Hindu nationalism and Kali worship which were rationalized as different expressions of the same 'uncivilized' bloodlust of the Indians (Urban 2003, 86). For instance, Sir George MacMunn saw the bomb parast or the bomb worshipping Indian nationalists as being driven by a spirit of religious fanaticism. Interestingly, he makes an explicit connection between the Thugs, the rebelling Sepoys of 1857 and the bomb parast Indian nationalists. The bomb parast nationalists were seen as the spiritual descendants of the Thugs and the 'murdering' Sepoys. To quote MacMunn:

As Bowani and Kali were the patron saints of Thuggism before which ruthless blood cult, young nor old, maiden or matron, man nor boy were spared, so does the sakti of Siva shed her blessing, in the opinion of her votaries to those to whom Kali makes her cry "Main bookhi hun! Main bookhi hun!" (Intone it nasally) "I want blood! blood! blood!" At Cawnpore she got it brimming over, the women's breasts sliced off, the children, Hindu and Moslem, torn asunder to make a Hindu holiday, by many hundred. "Mian bookhi hun! Main bookhi hun!" (Macmunn 1933, 219)

One needs to note the hyperbolic language. MacMunn's premise is that in rebelling against the British, the Indians are not inspired by any feeling of patriotism but by mere irrational 'superstition' and bloodlust. Of course, MacMunn was by no means the only writer to present the matter in this light. Even before him, others like Alfred Comyn Lyall and Valentine Chirol had tried to explain away Indian nationalism as expressions of Hindu fanaticism by linking it with Kali worship (Lyall 1910, xii - xv; Chirol 1910, 102 - 105). These examples make clear that the British colonizers often invoked the worship of Goddess Kali, with Thuggee as its offshoot, for explaining Indian resistance to colonial rule.

According to Urban, "[I]n the colonial imagination" Tantra or Kali worship came to stand for "the presence of a savagery that [could not] be colonized, an irrational, violent, and sexual power that threatens to consume the white masters" (Urban 2003, 87). While agreeing in the 
main with this perception, I argue that the case is slightly different with Thuggee. It is indeed true that Thuggee continued to inspire anxiety-ridden narratives long after it was officially declared extinct. As will be shown later, several writers of fiction like Sir Arthur Conan Doyle, Jules Verne, Emilio Salgari and others maintained that it was never completely eradicated and could resurface at an opportune moment. To these writers, Thuggee certainly stood for an untameable aspect of Indian 'savagery'. But it is also the case that the British writers, particularly those involved with colonial administration, saw Thuggee in a somewhat different light. They were conscious that the anti-Thuggee campaign represented one of their greatest triumphs in India. In the words of Patrick Brantlinger, "If Thuggee showed the worst side of Hinduism to British readers, its suppression seemed to show the greatest benefits of British rule and civilization" (Brantlinger 1988, 90). Wagner too states, "the suppression of thuggee assumes a place of honour within the colonial history of the Raj" (Wagner 2014, 2). Consideration of this fact compels us to reject the simplistic idea that the later colonial writers mentioned Thuggee only to admit their own failure in taming the 'savagery' of the Indians. Instead, I believe that the British writers sometimes invoked it because it reminded them of their success. This in turn increased their self-confidence, particularly during hours of crisis.

In this context, it is necessary to note that the British colonial officials in India tended to remember Thuggee specifically at those times when they became conscious of the necessity of introducing some major changes in Indian administration. For instance, the publication of Sir George MacMunn's book in 1933 not only coincided with the intensification of revolutionary terrorism in Bengal ${ }^{7}$ but also with the summoning of the Round Table Conferences in London $(1930-1932){ }^{8}$ The Round Table Conferences had to be summoned because the Indians were clamouring for more autonomy in matters of governance. Living at that period, MacMunn could not have been oblivious to this..$^{9}$ Therefore, in sketching seamy details of the Indian underworld, he was in effect arguing against granting the Indians self-rule. He seems to suggest that being inadequately 'civilized', Indians would lapse into 'savagery' and 'barbarism' once British grip on them has been slackened. MacMunn actually mentions that Thuggee may "easily return in an India that has lost the resolute mainspring from its policy" (MacMunn 1933, 199). This is not admission of defeat on his part. Rather, MacMunn is calling for the exercise of caution while introducing innovations in governance. At the same time, by insisting that Thuggee continues to exist in a different guise, he is calling for the continuation of British civilizing 'mission' in India. In other words, for him, Thuggee calls for action. In course of this, it is detached from its proper historical context and presented as a timeless phenomenon. One finds almost the same thing occurring during the Mutiny of 1857 when some British thinkers invoked Thuggee to sound a clarion call for furthering British mission in the subcontinent.

So much scholarship has been lavished on the Uprising of 1857 that any formal introduction to it appears unnecessary. As with Thuggee, scholars continue to debate over its nature. As Malik has shown, even nineteenth century British understanding of the Mutiny was not homogenous. He observes:

From its inception and for sometime thereafter, writers have ... described the revolt as a "Great Mutiny," a "social rebellion miscalled a military mutiny," a "servile war and a sort of Jacquerie combined," a "Revolution" comparable to the French revolution and the American War of Independence, a "patriotic war," a "Brahamanical protest," a "national movement in the fullest sense," a "Muslim rebellion," a "Dalhousie aftermath produced by the modernistic and imperialistic policies of that Governor General between 1848 and 1856," and a "Russian intrigue” (Malik 1973, 95 - 96). 
One among these views was the belief that the Mutiny was a manifestation of the Christian God's wrath on the British people for failing to convert the Indians to Christianity. At the same time, the British believed that it was "designed to arouse the people of Britain from their past slumber and to alert them to their duty" of Christianizing India (Malik 1973, 107). The Mutiny was thus seen as "Providential" in this sense. Significantly, Taylor subscribed to this view. In one of his letters written to his family in England dated 21 June 1857, he observes:

This, too, may have been one of those solemn warnings, given in God's providence, resulting from struggles in men's minds between forms of belief - the fact between heathenism and Christianity. What the Saxons were to Charlemagne, the Hindoos (sic), mutatis mutandis, may be to us. A great struggle between light and darkness, civilisation and savages, is no doubt progressing ... (Taylor 1878, 340).

The reference to Providence can be likewise traced in another of his work entitled Memorandum on the Future Government of India (1858), ${ }^{10}$ where he states:

But they [the rebels] have not had the victory; they will not have it. Their plans have been confounded by a power which has stricken down our own people in a terrible manner, which has chastised us fiercely and ruthlessly for a moment, yet wisely and majestically as refers to the future ... (Taylor 1858,41 ).

It might be noted that both works claim that the Christian God finally sided with the British. The Mutiny was explained away as an angry father's warning to his errant sons. Moreover, Taylor discerns in the Mutiny a call for further action. In his view, the Mutiny adequately revealed that the colonial mission of 'civilizing' and Christianizing the Indians needed to be continued with a greater vigour (Taylor 1878, 350; Taylor 1858, 14). He thus declares in Memorandum on the Future Government of India that "the conquest of India, in its noblest sense, is only now commencing" (Taylor 1858, 7).

Consideration of the above mentioned factors help us understand why some colonial writers like Taylor discerned a connection between the Thugs and the mutineers. First, it helped them undermine Indian resistance. As Wagner explains,

By imbuing Thuggee with a seditious anti-colonial agenda, such popular representations confuse the historical acts of anti-colonial sentiments with what is regarded as barbaric and superstitious acts. The aspiration of the Thugs and the rebels of 1857, as well as revolutionary nationalists of the later nineteenth century, are in effect conflated and reduced to similar expressions of irrational Oriental fanaticism (Wagner, 2013, 161).

More importantly, these writers invoked Thuggee and the Mutiny to argue for the continuation of British rule in India for an indefinite period. They claimed that the Thugs and the mutineers revealed the persistence of 'fanaticism' or non-Christian beliefs in India which still needed to be rooted out. As Taylor and the likeminded would have it, it was divine Providence that had chosen the British to enlighten/civilize the Indians. Hence, their rule in India was sanctioned by the Christian God.

Having explained why some British thinkers in the colonial period sought to establish a connection between Thuggee and the Sepoy Mutiny, we move on to examine how this was actually done. In the process, we will also notice the difference between British and Continental approach in this matter. The following section takes up for analysis those late nineteenth and early twentieth century texts which interconnect Thuggee and the Mutiny. 


\section{Intertwining Thuggee and the Sepoy Mutiny in Colonial Fiction}

One should note at the outset that colonial works which link Thuggee with the Sepoy Mutiny are not many in number. What adds to our difficulty is the fact that this area has not received sufficient critical attention till now. Probably this is because, not many historical writings of the colonial era explicitly link Thuggee and the Mutiny. This is only to be expected, since the former expired long before the emergence of the latter. As Wagner states,

In 1839, Sleeman declared that Thuggee as an organized association had been effectively destroyed and even though some cases occasionally occurred in the course of the following decades, the thuggee campaign was over (Wagner 2014, 228).

Thus to claim that the Thugs were still functioning in 1857 was to run the risk of being criticized for anachronism. Moreover, no real evidence has been discovered yet which may prove that the Thugs and the Sepoys conspired together against the British. ${ }^{\text {In }}$ Such conjectures properly belong to the realm of fiction. But even the British Mutiny novels rarely suggested that connection. This is natural since early British novels on the Mutiny were characterized by a myopic gaze that focused more on the Britons than on the Indians. Characterized by scholars as "national epics", ${ }^{12}$ these novels were panegyrics on British heroism and valour. ${ }^{13}$ They were not usually the types to look beyond the commonplaces. It is only exceptional works like Taylor's Seeta (1872) which tried to probe into the causes of the Mutiny. As will be shown, in this attempt Taylor became the first British writer to suggest a connection between Thuggee and the Mutiny. His view on this matter influenced later writers.

Before taking up Seeta, one should note that Taylor had explicitly suggested a connection between Thuggee and the Mutiny once before in one of his "Letters Home". The letter dated $7^{\text {th }}$ September 1857 reiterates his favourite theory that the Mutiny was "a movement of savagery against civilisation". Here Taylor's particular target is the Brahmins of Oudh (Ayodhya) who formed the main body of the insurgent sepoys. He claims that these Brahmin sepoys were the votaries of Kali and were related to the Thugs. They came from the very same districts, and "most noted leaders" of the Thugs belonged to the same class as Oudh Brahmins (Taylor 1878, 348). One finds that this line of reasoning is too frivolous and weak to support any definitive conclusion. Which is why, Taylor never built upon the idea further in any of his historical works. But he did not give it up for good either, returning to it in his novel Seeta.

Seeta depicts the interracial romance between the eponymous Indian heroine and the British hero Cyril Brandon in the backdrop of the Mutiny. At first sight, this novel does not point to a direct connection between the Thugs and the insurgent sepoys. This is because Taylor's target of attack here is not Thuggee but Dacoity. Though these were often uttered in pairs, the British usually distinguished between the two. For instance, an article entitled "What is Dacoity?", published in London Society in 1886 , defines Dacoity as "gang robbery perpetrated by violence, most frequently by night, and often attended with bloodshed" (Anonymous 1886, 294). It thereby specifically differentiates it from Thuggee. Azráel Pandé, the main antagonist in Seeta, represents one of the "treasonable emissaries of the time" (Taylor n.d. a, ix -x). He is a dacoit leader and not a Thug. In fact, Thuggee is mentioned only twice in the first volume of the novel where it is described as a thing of the past. Taylor praises the extermination of Thuggee, hoping that British campaign against Dacoits would meet with the same level of success (Taylor n.d. a, 10, 204). Nevertheless, as both Patrick Brantlinger and Maíre ní Fhlathúin suggest, the figures of Thugs and Dacoits merge in Azráel Pandé. ${ }^{14}$ Brantlinger observes, 
Taylor's version of the Mutiny seems at first to be an extension of Thuggee, because the chief conspirator, Azrael Pande, is a former Thug, who disguised as a Muslim priest, goes about the countryside preaching rebellion (Brantlinger 1988, 212 - 213).

It needs to be observed that this statement is not entirely accurate as Taylor nowhere calls Azráel a Thug. Nor did Azráel disguise himself as a Muslim priest. He posed as a Hindu "Jogee" (yogi) to preach sedition (Taylor n.d. b, 264; also, Taylor, n.d. c, 254). Maíre ní Fhlathúin is more cautious in her claim. She circumspectly observes, "It is through the figure of Azráel Pandé that Seeta develops a link between the thugs and dacoits of the 1830 and 1840 , and the rebels of 1857 " (ní Fhlathúin 2017, 154 - 155). This is certainly true. One notes that Azráel is not simply a Dacoit. He was also an ex-sepoy who was "discharged for insubordination" (Taylor n.d. a, 177). Moreover, he is also the (fictional) uncle of the famous Mungul Pandé (Mangal Pandey). The sepoy Mangal Pandey had played a key role in the Mutiny. By making him the nephew of Azráel "Taylor draws a straight line from the alienated bandit to the nationalist rebel”, as ní Fhlathúin correctly observes (ní Fhlathúin 2017, 155). However, most scholars miss an important point. The novel subtly hints that before taking up Dacoity as his profession, Azráel must have worked as a Thug. This becomes clear in volume II where he threatens to strangle the Mughal emperor's envoy from Delhi Moulvee (Mawlawi) Zea Oolla. The text mentions that, "taking a small thin handkerchief from his waist, Azráel began to handle it in an ominous manner" (Taylor n.d. b, 263). As one may recall, in British eyes, the Thugs' favourite method of killing was strangling their victims with a handkerchief or rumal. It was one of those factors that made them different from other types of criminals, including Dacoits. Even in Thug gangs, strangulations were usually carried out by experts called bhurtote (for details see Woerkens 2002, 121). If Azráel was simply a dacoit leader, he could not have known the art of strangling. Especially since this was never the method of the dacoits, who preferred direct attack with arms. Seeta also shows that Azráel operated under many aliases like Moolráj or Gungah Singh (Taylor n.d. a, 9, 177). Again, this was a practice typically associated with the Thugs. These details seem to indicate that Azráel must have been a Thug before switching over to Dacoity. Here one may object that Taylor could have easily made his villain a Thug if he really wanted to do so. He had no need for being so chary. However, one may point out that Taylor could not present Azráel as a Thug because he prided himself on his accuracy. Admitting that the Thugs were still at large in 1857 was as good as accepting the failure of the British anti-Thuggee campaign. This would have been particularly difficult for a colonial administrator like Taylor, who claimed to have actively participated in that operation (see Taylor $1878,72-73$ ). So he circumspectly suggests that some Thugs had escaped the British by switching over to Dacoity.

So why did Seeta suggest a connection between Thuggee and the Sepoy Mutiny, even if this is done obliquely? It is easy to see that the novel reflects Taylor's idiosyncratic understanding of the Mutiny. If one reads Seeta in conjunction with "Letters Home" and his father's 1858 "Preface" to Confessions of a Thug, it becomes evident that the author saw Thuggee and the Mutiny as conspiracies having their roots in Hindu 'fanaticism' with Goddess Kali as its icon. Significantly, Azráel mentions at one place that the English were the "direst enemies" of Mother Kali (Taylor n.d. b, 38). This position appears remarkably similar to MacMunn's line of thinking. Like him too, Taylor was not simply condemning Indian resistance against foreign rule. At the time when the author was writing the letters to his family and Memorandum on the Future Government of India, he was aware that the British government needed to introduce changes in the administration of India. At that crucial hour, he felt it his duty to call for the continuation of 
the 'civilizing mission'. This was natural for a colonial administrator like him. One finds that even in Seeta, there is a veiled call for action. The protagonist Cyril Brandon realizes that the Mutiny had been an eye-opener for him, since it made him understand many problems faced by the Indians which he was previously unaware of (Taylor n.d. c, $266-2267$ ). Taylor thus suggests that, armed with this newly gained knowledge, the British would be able to continue with their 'mission' more efficiently.

One needs to note that few of Taylor's immediate contemporaries in Britain discovered any connection between Thuggee and the Sepoy Mutiny. He did it, probably because he was involved in both the affairs. But one finds that some later British writers followed him in intertwining these two events. Sir Arthur Conan Doyle $(1859-1930)$ provides us with a good case in point. His short story "Uncle Jeremy's Household" was serialized in the periodical The Boy's Own Paper between $8^{\text {th }}$ January and $9^{\text {th }}$ February 1887 (Siddiqi 2008, 37, sic passim). Hugh Lawrence, the narrator in the story, admits having read Taylor's works on Thuggee. He declares, "The Thugs! ... I remember an account of them which I had read in the works of Colonel Meadows Taylor ...” (Doyle 2012, n.p.). This is clearly Doyle acknowledging his debt to his predecessor. A most appropriate gesture, given that like Taylor he yokes Thuggee with the Mutiny in this story. The story describes the narrator's adventure in a country house, where he comes to live with his friend and his uncle as their guest. Lawrence soon discovers to his horror that Miss Warrender, the attractive Eurasian governess, is in reality a princess of the Thugs. He further learns that Uncle Jeremy's private secretary Mr Copperthorne intends to employ Miss Warrender to kill his employer. His plan is to prevent his employer Uncle Jeremy from changing his will and bequeathing everything to the narrator's friend instead of him. Before Lawrence can stop Copperthorne, a Thug associate of Miss Warrender kills the villainous secretary. Miss Warrender and the Thug vanish forever, presumably to return to India. The narrative ends with a plea for spreading the gospel in India, which alone is deemed capable of "effectually" dispelling Thuggee (Doyle 2012, n.p.).

In conflating Thuggee with the Sepoy Mutiny, Doyle's story is more straightforward than Taylor's novel. Miss Warrender is the daughter of an unnamed English woman and "a semiindependent chieftain" named Achmet Genghis Khan. The thug leader Achmet had joined Nana Saheb in his rebellion against the British. The British killed him in retaliation and confiscated his estate (Doyle 2012, n.p.). His destitute and orphaned daughter was adopted by a German merchant and brought to Europe. Yumna Siddiqi, who studies the story in detail, argues that Miss Warrender represents the imperial lumpenproletariat and that the narrative reflects Doyle's mistrust of the Eurasians (Anglo-Indians) and miscegenation (Siddiqi 2008, sic passim). In the course of her analysis of the story, she tries to explain while Doyle "yoked together" Thuggee and the Mutiny. She argues that since "both loomed large in the popular imagination" their intertwining "made obvious subject matter for a sensational story" (Siddiqi 2008, 53). More importantly, she feels that by conflating the two the story seeks to belittle the political implications of the Mutiny. In the words of Siddiqi, "Misgivings about the motives and meanings of the Mutiny are rhetorically displaced into Thuggee" in order to "delegitimize its political aims and render its threats moot" (Siddiqi 2008, 56). While this is indeed a proper explanation, Siddiqi fails to take into account the ending which prescribes the dissemination of the gospel as the remedy for administrative problems in the colony. In my opinion, this fact requires more consideration. As I understand, by showing that Thuggee existed at a period when it was officially declared extinct, the story tacitly acknowledges British failure in curbing Thuggee. The implication is that the colonizers failed to tame the Indians. But by suggesting a remedy, the story also ends on a hopeful note. The call to spread the gospel is in reality a call to carry on with the 
civilizing mission in India. Doyle does not simply articulate the 'anxieties of the Empire' as Siddiqi suggests. He also preaches the continuation of the civilizing mission.

In his study of Hermann Goedsche's $(1815$ - 1878) forgotten Mutiny novel Nena Sahib, oder: Die Empörung in Indien ['Nana Sahib, or: The Uprising in India'] (1858 - 59), ${ }^{15} \mathrm{Kim}$ A Wagner draws our attention to the rare "Continental European perspective on 1857, which completely inverts the British literary representations, while at the same borrowing heavily from the conventional repertoire of Orientalist Stereotypes" (Wagner 2013, 150). This practice of inverting British representations of the Mutiny while accepting many Orientalist stereotypes characterizes several non-British fictions that correlate Thuggee and the Mutiny. Admittedly, not all nonBritish writers followed the same practice. Jules Verne, for instance, adhered to traditional British representations of the Sepoy Mutiny in his novel The End of Nana Sahib [alternate title La Maison à Vapeur ('The Steam House'), 1880]. Interestingly, he describes Nana Saheb finding refuge in "Bundelcund" [Bundelkhand] among the Thugs, Dacoits and Pindaris (Verne 2011, 240 - 241). Verne thus suggests a connection between Thuggee and the Mutiny by hinting at a kinship between the Thugs and the leader of the mutineers. In doing so, he certainly follows the British practice of disparaging Indian insurgency. However, Goedsche and some other non-British writers take a different stand. As Wagner shows, Goedsche develops a critique of British colonialism in his novel. His Nana Saheb is not a demon but an injured innocent who is driven to rebellion by British misdeeds. ${ }^{16}$ To avenge himself and his countrymen, the prince joins the Thugs led by Tukallah or Tantia Topi. As Wagner shows, the Thugs are not exonerated from charges of cruelty and fanaticism in this novel (Wagner 2013, 160). Goedsche does not entirely condone the alleged brutality of the mutineers either (Wagner 2013, 161-164; also, Bhatti 2011, 146 - 147). At the same time, the author holds the British responsible for driving the Indians to extremity. Wagner states, "For Goedsche the conspirators of 1857 were the heroes while the British brought the uprising upon themselves through their greed and tyranny" (Wagner 2013, 153, also 164). This novel, which precedes the first English Mutiny novel, thus stands out from most other writings of that period.

Goedsche is certainly not the only Continental novelist to criticize British colonialism in India. Nor is he the only non-British writer to intertwine Thuggee and the Sepoy Mutiny. The famous Italian author Emilio Salgari (1862 - 1922) takes the same approach. His "Sandokan series" comprises eleven novels, several of which are set in India. Of these, the second and the fourth novel have the Thugs as the antagonists. The second novel The Mystery of the Black Jungle (1895) narrates the adventures of the Bengali hunter Tremal-Naik and his loyal Maratha servant Kammamuri who fight the Thugs led by Suyodhana to rescue Tremal's beloved Ada Corishant. Ada was kidnapped in her childhood by the Thugs to serve as the priestess of Goddess Kali against her will. In the sequel Sandokan: The Two Tigers (1904), the Malaysian pirate-prince Sandokan and his Portuguese comrade Yanez de Gomera rushes to India to help their widowed friend Tremal-Naik. The Thug leader Suyodhana had kidnapped Tremal's infant daughter Darma to make her the new high priestess. A deadly contest ensues between the pirates of Malaysia and the Thugs of India, which ends with the routing of the Thugs and the death of Suyodhana. This novel is set against the backdrop of the Uprising of 1857, with the Thugs joining the mutineers in their fight against the British colonizers.

Salgari's representations of both Thuggee and the Sepoy Mutiny are ambivalent. He was certainly more liberal than average British and Continental writers of his times. Unlike them, he depicts successful interracial romances in his novels - like those between Tremal-Naik and Ada, Sandokan and Marianna, and Yanez and Surama. He is often praised as an anti-colonial writer 
who criticized British imperialism in particular (Orsini 2018, 11, 17). At the same time, his novels are full of orientalist clichés. One is reminded of Francesca Orsini's observations in this regard:

... while Salgari was definitely a libertarian, in the tradition of the Risorgimento ... he was not, could not be, outside the episteme of his times, which viewed Europe as more advanced than Asia and did not question the dominance of European empires ... Salgari's pervasive reliance on, and enchantment of, orientalist and racial stereotypes reinforced feelings of cultural difference, superiority, and non-coevalness (Orsini 2018, 16)

The ambivalent nature of Salgari's worldview becomes obvious when one considers his representation of the Thugs. On the one hand, following the colonial tradition, he stereotypes them as bloodthirsty fanatics and followers of an abominable death cult. As scholars point out, Salgari is "fiercely critical" of Hindu Gods and holy men. His novels seemingly sharpen "ethnic and religious biases" (Orsini 2018, 13). On the other hand, the author does hint that the Thugs are in a way involved in anti-colonial protests. In The Mystery of the Black Jungle Suyodhana invites Tremal-Naik to join the Thugs because, like them, he is also "an Indian who languishes beneath the yoke of our oppressors." Justifying his method, the Thug leader states, "The British kill us with guns and cannons; we fight back with our rumaals (sic), the weapon of our nighty goddess" (Salgari 2013, 274). These declarations show that Salgari's Thugs are motivated by patriotic zeal, even if in a twisted way. In Sandokan: The Two Tigers the author depicts the entente between the Thugs and the mutinous Sepoys. Again, his portrayals of both groups are ambivalent. The Sepoys are described as rebels who "have no manners" and who "skinned every Englishman they could find, without sparing women or children" (Salgari 2010, 236, 240). Yet, they are also acknowledged as "fighting for India's freedom" (Salgari 2010, 224, 238). The Thugs are portrayed in even darker colour in this novel. Salgari hints that the Sepoys and the Thugs are united in an uneasy alliance. The subedar or the leader of the Sepoys cannot counter Tremal's allegation that the Thugs are "wretched murderers despised throughout India" (Salgari 2010, 237). Yet, these same Thugs bravely oppose the British and perish during the final seize at Delhi (Salgari 2010, 264). Notably, Salgari nowhere defends the British. He condemns their massacre of the innocents, including women and children, after Delhi is taken (Salgari 2010, $270-271$ ). In his view, the British have failed the Indians who are justified in rebelling against them.

The novels of Hermann Goedsche and Emilio Salgari thus show how the non-British writers used the same representational strategy as the British colonizers to serve a significantly different end. It is to be noted that none of these writers actually sympathized with Thuggee. Following the British tradition, they saw it as a 'barbarous religion of murder' or a death cult. But the yoking of Thuggee with the Sepoy Mutiny serves a different purpose in their novels. Like the British authors discussed earlier, these Continental authors do not essentially disparage Indian insurgency when they link Thuggee with the Mutiny. They seem to argue that the British brought the Mutiny upon themselves by failing in their civilizing mission. It may be pointed out that this was a common perception in Italy and Germany. For instance, Chiara Cherubini writes that the Italian press at that time almost unanimously condemned the East India Company for "its ineffectiveness in moulding the distant Indian society along European cultural and political ideals" (Cherubini 2011, 68). To many of these Continental writers, the (alleged) continuing existence of Thuggee in British India became the index of British failure in civilizing the Indians. Thus while the British authors interpreted Thuggee and the Mutiny as 'providentially' arranged incidents that called for continuation of the 'colonial mission' with renewed vigour, many nonBritish authors understood these as irrefutable signs of British failure. Though these non-British 
writers did not really appreciate Indian religions or culture, they nevertheless display some sympathy with the Indian insurgents. It is to be noted that writers like Goedsche and Salgari came from countries that joined the race for colonial expansion much later than England and France. Their criticisms of British rule in India have to be seen in that context. ${ }^{17}$ What they criticized was not colonialism itself. Instead, their target was a particular brand of it - namely, British colonialism. Often, the underlying implication was that the civilizing mission would have been better handled if it was carried out by the writer's own country.

Finally, one remembers the Goan writer Francisco Luis Gomes' (1829 - 1869) novel Os Brâmanes [The Brahmans] (1866). Though born in India, Gomes was by birth a Portuguese. He naturally identified himself more with the Portuguese ethos than with the Indian. As Ben Antano describes, The Brahmans "is a story of inter-caste and inter-racial love, faith and sacrifice" (Antano 2013, n.p.). Gomes is hailed in our times as a crusader against slavery and a defender of the civil rights of the colonized people. However, both Everton B. Machado and Govinda. N. S. draw our attention to the anti-Brahmin polemic in the novel. As both separately show, the novel actually calls for the Christianization of India through the demolition of 'Brahmanism' (Hinduism) and the conversion/subjugation of Brahmins (Govinda 2016, sic passim; Machado 2011, 253, 262; also, Ranganathan 2011, 276). Notably, one again finds the yoking of Thuggee and the Sepoy Mutiny in the novel. Magnod, the Brahmin antagonist, becomes a Thug and a mutineer in succession. Govinda establishes that the novelist criticizes Thuggee in no uncertain terms, associating religion with criminality to vituperate against Hinduism (Govinda 2016, 51 - 54). Machado points out that by associating Thuggee with the Mutiny the author "reduces the importance of the indigenous rebellion" (Machado 2011, 256). At the same time, Gomes is critical of British colonialism. As Machado points out, "Brahmans" in the title refer to the British as well who are criticized for being exclusivists (Machado 2011, 254; also, Ranganathan 2011, 274). Gomes seems to feel that the British had botched up their mission of civilizing/Christianizing the Hindus. That is why he connects Thuggee and the Sepoy Mutiny in the novel, which happens in British India but not in Portuguese Goa (Govinda 2016, 42). However, by criticizing British colonialism in India, was Gomes suggesting in effect that the Portuguese would have done a better job? The readings of Govinda and Machado seem to suggest this (Govinda 2016, sic passim; also, Machado 2011, 251).

\section{Conclusion}

This article thus brings to light several important facts. First, one notes that the idea that the Thugs and the mutineers were united by a common cause originated independently and almost simultaneously in Britain and the Continent. While Taylor hints to this in 1857, Goedsche articulates it in $1858-59$. Goedsche certainly arrived at this idea independently, because Taylor's letters to his family were initially printed for private circulation only. They were appended to his posthumously published biography much later in 1878. However, Taylor never directly acknowledged that the Thugs were involved in the Mutiny. As already stated, he could not contradict the fact that Thuggee officially became extinct before 1857 . The non-British writers enjoyed more freedom in this respect. Secondly, the intertwining of Thuggee with the Mutiny served different purposes for different writers. The British conflated these two to indicate the lawlessness of the Indians. Their efforts were to undermine the grievances of the Indians and to justify the continuation of British rule in India. In contrast, the Continental writers invoked Thuggee and the Mutiny to point to the failure of the British civilizing mission in its colonies. Their attitude to the Sepoy Mutiny was more ambivalent, neither entirely dismissive nor totally 
supporting. Thus this study shows how the same representational strategy could serve different ends.

This article attempts to situate Thuggee within the broader discourse on Indian insurgency. Already within the tradition of Thuggee scholarship there exist the minority view that the Thugs were involved in anti-colonial resistance (for an overview see Chakraborty 2019, 346). While not subscribing to that opinion, this article shows that at least some colonial writers conceived of Thuggee as a sort of resistance even if of a perverted kind. In this way, the article indicates that an alternative way of conceptualizing Thuggee had been forwarded even by the colonizers themselves.

Finally, this article problematizes the naïve assumption that nineteenth and early twentieth century European representations of the Orient were unvarying in nature. It shows that the same events evoked different responses from people of different nations. However, this does not indicate that the basics of colonial episteme were challenged. The primitiveness and backwardness of the Orientals were accepted by all Occidental writers. The examination of representations of Thuggee and the Mutiny in colonial fictions again supports this understanding.

\section{Endnotes}

${ }^{1}$ The insurrection that happened in India in 1857-1858 has been interpreted, understood and described in various ways. In this article, I prefer to stick to the old-fashioned 'Sepoy Mutiny' as that was how all the writers under discussion described it.

${ }^{2}$ It was signed "P.M.T.".

${ }^{3}$ Bentley and the author party were not the only ones who attempted to make capital of the situation. Hilda Gregg points out that many other writers of that time tried to "utilise the flowing tide of popular excitement for their own advantage" (Gregg 1897, 219). Salahuddin Malik also draws our attention to this fact (Malik 1973, 104-106).

${ }^{4}$ Sleeman and his colleagues claimed that both Hindu and Muslim thugs worshipped Goddess Kali. Several contemporary scholars express their reservation about this claim (see for instance Humes 2003, 160).

${ }^{5}$ Sleeman $(1788-1856)$ was the scourge of the Thugs, as Chatterjee rightly calls him (Chattterjee 1999, 126). He has since become famous for spearheading British campaign against Thuggee.

${ }^{6}$ The British colonial authorities acknowledged that the Thugs never harmed the Europeans.

7 The Civil Disobedience movement, launched by M. K. Gandhi in 1930, preceded the publication of MacMunn's book by just two years.

${ }^{8}$ For the general historical data, the article is indebted to An Advanced History of India by Majumdar, Raychaudhuri and Datta. The Round Table Conferences ultimately paved the path to the promulgation of the Government of India Act in 1935, which granted a greater degree of autonomy to the provinces of British India.

${ }^{9}$ Lieutenant-General Sir George Fletcher MacMunn (1869 - 1952) of the British army served at various places including India. He wrote many fiction and historical works, several of which were set in India. He was one of the founders of the Kipling Society.

${ }^{10}$ This forgotten work was printed for private circulation and was never separately published. I was fortunate to discover a copy of this rare piece in the British Library, London. 


\footnotetext{
${ }^{11}$ Wagner does point out that at Meerut the Thugs joined the Sepoys after the latter stormed the old jail and set the prisoners free (Wagner 2010, 146). But this was just happenstance, and does not indicate a conspiracy.

${ }^{12}$ The term "national epics" was used by Nancy L. Paxton to characterize the Mutiny novels (Paxton 1999, 114; also, Brantlinger 1988, 202).

${ }^{13}$ There were definitely exceptional novels like Hume Nisbet's The Queen's Desire that revealed more sympathy for the Indian insurgents. For details one should consult Gregg, Paxton and others (Gregg 1897, 224).

${ }^{14}$ In a footnote in his article "Vengeance Against England!' Hermann Goedsche and the Indian Uprising" Kim A. Wagner declares that Azrael Pande was a former Thug (Wagner 2013, 167). But he does not explain how he came to this conclusion. Though I agree to this view, Taylor does not state this explicitly anywhere in his novel.

${ }^{15}$ The novel was written under the pseudonym Sir John Retcliffe (Wagner, 2013, 150).

${ }^{16}$ In the novel Nana Saheb's Irish wife is abducted by an Englishman who wants to sexually exploit her. The wife becomes insane and dies shortly after (Wagner, 2013, 152).

${ }^{17}$ Both Wagner and Orsini suggest this reading (Wagner 2013, 165; Orsini 2018, 6).
}

\section{References}

Antano, Ben. (2013). Goan Literature in English. Muse India, 50, n.p. http://www.museindia.com/Home/ViewContentData?arttype=focus\&issid=50\&menuid=4273.

Anonymous. (1886). What is Dacoity? London Society, 49(291), 290 - 297.

Bhatti, Anil. (2011). Retcliffe's Nena Sahib and the German Discourse on India. In Shaswati Mazumdar (ed.), Insurgent Sepoys: Europe Views the Revolt of 1857 (pp. 137 - 151). Routledge.

Brantlinger, Patrick. (1988). Rule of Darkness: British Literature and Imperialism, 1830 - 1914. Cornell University Press.

Chakraborty, Ayusman. (2019). Baagi or Thagi? Representations of the Thugs in some Mainstream Commercial Films. Literary Endeavour, x(2), 343 - 351.

Chatterjee, Amal. (1998). Representations of India, 1740 - 1840: The Creation of India in the Colonial Imagination. Macmillan Press Ltd.

Cherubini, Chiara. (2011). Freedom and Democracy: The Revolt in the Italian Press. In Shaswati Mazumdar (ed.), Insurgent Sepoys: Europe Views the Revolt of 1857 (pp. 63 - 78). Routledge.

Chirol, Valentine. (1910). Indian Unrest. Macmillan and Co., Limited.

Doyle, Sir Arthur Conan. (2012). Uncle Jeremy's Household. In Collected Stories of Arthur Conan Doyle (n.p.). Project Gutenberg Australia. http://gutenberg.net.au/ebooks12/1200771h.html. (Original work published in 1887)

Finkelstein, David. (1990). Philip Meadows Taylor (1808 - 1876): A Bibliography. Victorian Fiction Research Unit, University of Queensland.

Gomes, Francisco Luis. (1971). The Brahmans (Armando Menezes, Trans.). Sindhu Publications. (Original work published in 1866)

Govinda, N. S. (2016). Representation of Brahmins and Brahminism in Indian English Novels, Translated Novels, and Autobiographies. [Doctoral dissertation, Mangalore University]. Shodhganga. http://hdl.handle.net/10603/209348. 
[Gregg, Hilda]. (1897). The Indian Mutiny in Fiction. Blackwoods Edinburgh Magazine 161 (976), 218 - 231.

Humes, Cynthia Ann. (2003). Wrestling with Kālī: South Asian and British Constructions of the Dark Goddess. In Rachel Fell McDermott and Jeffrey J. Kripal (Eds.), Encountering Kālī: In the Margins, at the Centre, in the West (pp. 145-168). University of California Press.

Lyall, Sir Alfred C. (1910). Introduction. In Valentine Chirol, Indian Unrest (pp. vii - xvi). Macmillan and Co., Limited.

Machado, Everton B. (2011). The Rebellion in a $19^{\text {th }}$-century Indo-Portuguese Novel. In Shaswati Mazumdar (ed.), Insurgent Sepoys: Europe Views the Revolt of 1857 (pp. 251- 266). Routledge.

MacMunn, Sir George. (1933). The Underworld of India. Jarrolds Publishers.

Majumdar, R.C., H. C. Raychaudhuri and Kalikinkar Datta. (2010). An Advanced History of India (4 ${ }^{\text {th }}$ ed.). Macmillan Publishers India Limited.

Malik, Salahuddin. (1973). Nineteenth Century Approaches to the Indian "Mutiny". Journal of Asian History, 7(2), 95 - 127. https://www.jstor.org/stable/41930097.

ní Fhlathúin, Máire. (2017). British India and Victorian Literary Culture. Edinburgh University Press.

Orsini, Francesca. (2018). Mysteries of the Indian jungle: Emilio Salgari's Orientalist adventures. Draft. Academia.edu.https://www.academia.edu/37799508/Mysteries of the Indian jungle?auto=download

Paxton, Nancy L. (1999). Writing under the Raj: Gender, race, and Rape in the British Colonial Imagination, 1830 - 1947. Rutgers University Press.

P.M.T. [Taylor, Philip Meadows (Sr)]. (n.d.). Preface. In Captain Meadows Taylor. Confessions of a Thug (n.p.). British Library. (Original work published in 1858)

Ranganathan, Balaji. (2011). Francisco Luiz Gomes's Os Brahamanes: The Uprising and Anglo-Indian Society. In Shaswati Mazumdar (ed.), Insurgent Sepoys: Europe Views the Revolt of 1857 (pp. 269 - 277). Routledge.

Reitz, Caroline. (2004). Detecting the Nation: Fictions of Detection and the Imperial Venture. The Ohio State University Press.

Roy, Parama. (1996). Discovering India, Imagining Thuggee. The Yale Journal of Criticism, 9 (1), 121 - 144. https://muse.jhu.edu/article/36735.

Salgari, Emilio (2013). The Mystery of the Black Jungle (Nico Lorenzutti, Trans.). ROH Press. (Original work published in 1895)

Salgari, Emilio (2010). Sandokan: The Two Tigers (Nico Lorenzutti, Trans.). ROH Press. (Original work published in 1904)

Siddiqi, Yumna. (2008). Anxieties of Empire and the Fiction of Intrigue. Columbia University Press.

Singha, Radhika. (1993). 'Providential' Circumstances: The Thuggee Campaign of the 1830s and Legal Innovation. Modern Asian Studies, 27(1), 83-146. http://www.jstor.org/stable/312879.

Sleeman, W. H. (1836). Ramaseeana, or A Vocabulary of the Peculiar Language Used by the Thugs. Military Orphan Press.

Taylor, Philip Meadows. (n.d.). Confessions of a Thug. British Library. (Original work published in 1858)

Taylor, Philip Meadows. (1858). Memorandum on the Future Government of India. John Edward Taylor.

Taylor, Philip Meadows. (1878). The Story of My Life. William Blackwood and Sons.

Taylor, Philip Meadows. (n.d. a). Seeta (Vol. 1). British Library. (Original work published in 1872) 
Taylor, Philip Meadows. (n.d. b). Seeta (Vol. 2). British Library. (Original work published in 1872)

Taylor, Philip Meadows. (n.d. c). Seeta (Vol. 3). British Library. (Original work published in 1872)

Urban, Hugh B. (2003). Tantra: Sex, Secrecy, Politics, and Power in the Study of Religion. University of California Press.

Verne, Jules (2011). The End of Nana Sahib; The Steam House (A. D. Kingston, Trans.). Rupa Publications India Pvt.Ltd. (Original work published in 1880)

Wagner, Kim A. (2009). Stranglers and Bandits: A Historical Anthology of Thuggee. Oxford University Press.

Wagner, Kim A. (2010). The Great Fear of 1857: Rumours, Conspiracies and the Making of the Indian Uprising. Peter Lang Ltd.

Wagner, Kim A. (2013). 'Vengeance Against England!' Hermann Goedsche and the Indian

Uprising. In Marina carter and Crispin Bates (Eds.), Mutiny at the Margins: New Perspectives on the Indian Uprising of 1857 (Vol. 3 Global Perspectives, pp. 150 - 169). Sage Publications India Pvt Ltd.

Wagner, K. A. (2014). Thuggee: Banditry and the British in Early Nineteenth-Century India. Primus Books. (Original work published in 2007)

Woerkens, Martine Van. (2002). The Strangled Traveler: Colonial Imaginings and the Thugs of India (Catherine Tihanyi, Trans.). The University of Chicago Press. (Original work published in 1995) 